\title{
Surgically Placed Gastrostomy Tube
}

National Cancer Institute

\section{Source}

National Cancer Institute. Surgically Placed Gastrostomy Tube. NCI Thesaurus. Code C122622.

A hollow tube that is inserted into a surgically created external opening into the stomach. 